$S B$ 253

156

American Flax Growers Waste $\$ 40,000,000$ Worth of Fiber Annually.

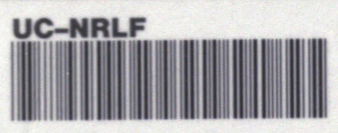

\$B ll? वb?

\title{
FLAX CULTUIS:
}

FOR TIHE SEED AND THE FIBER,

IN THE UNITED STATFES.

Published by HIRAM SIBLEV \& CO., Seedsmen,

Chicago, IIIs.

\section{ᄂ \\ J \\ $\infty$ \\ $\infty$

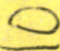




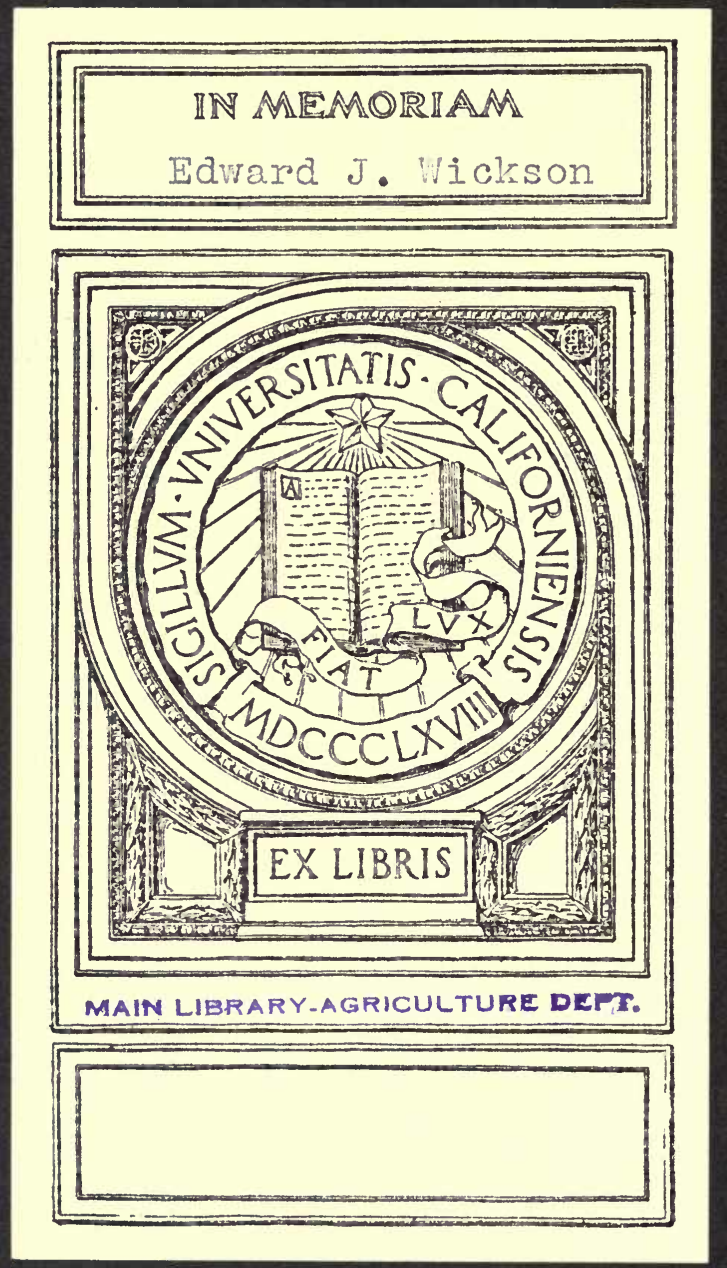




\section{Edward. J. Wickson.}

AMERICAN FLAX GROWERS WASTE \$40,000,000 WORTH OF FIBER AIRIUUALLY

\section{Flax CULTURE}

For the Seed and the Fiber,

IN THE UNITED STATES,

(b)

6

With Special Reference to the States West of Pennsylvania.

BY H. KOELKENBECK,

A Flax Grower and Manufacturer of Twenty-Five Years Experience in Ireland, Belgium, Russia and the United States.

Copyright, $188_{3}$, ву Hiram Sibley \& Co.

PUBLISHED BY

HIRAM SIBLEY \& CO., Seedsmen,

Rochester, N. Y., ANd Chicago, Ill

I 883 . 
I, $, 00,000$ acres, now annually sown with Flax, only I00,000 acres were devoted to the production of good Flax fiber, we would have enough to supply the home consumption and would have a surplus of ro, 000 tons for export to Europe. There is little doubt but that if this were the case, linen factories would soon spring up in our midst, and we would, in a few years, no longer pay tribute to the extent of over $\$ 25,000,000$ annually to Europe for the linen goods which we have to import for our yearly consumption; and this sum will naturally increase with the population.

No part of the inhabited globe offers so many advantages to this branch of agriculture and its development into a thriving industry, as our Western States. We have an admirable climate, fertile soil, abundant water power, such as no other country possesses, the most perfect machinery for harvesting, preparing the fiber and for any other purpose; ingenuity and spirit of enterprise, in short, every condition is present to ensure success.

The neglect of such a valuable product as Flax, and its gradual decline, in spite of efforts made from time to time during the last twenty years, has been attributed by some to the invasion of jute and an insufficient protective tariff, but it must be evident to any one who will take the trouble of looking into the real causes of the degradation of Flax production, that they are the following: Careless cultivation, the utter degeneracy and generally bad quality of the seed sown, the rough treatment of the fiber by the steamthreshing machine, and finally the want of a proper system for the economical preparation of the fiber for market. When these causes are removed, the Flax industry cannot fail to flourish in this part of the United States, and to occupy the rank it deserves among the national industries, and it is my earnest hope that this pamphlet may contribute somewhat to the removal of certain of the obstructions which have hitherto hindered its development.

H. K.

Fanuary, 1883 . 


\section{FLAX}

\section{ITS HISTORY.}

The native country of the Flax plant is unknown, though there is good reason to believe it to be Armenia; and no doubt it was from thence spread over all the countries known to the ancients. The cultivation of the Flax plant, and the manufacture of the fiber into cloth, are of very ancient date. The references to the fine linen of Egypt, and the purple and fine linen of Judea, in the Hebrew Scriptures, carry us back to a remote period, and show the antiquity of Flax and its products. Flax is first mentioned in Genesis xli, 42. Joseph, on his appointment as Viceroy of Egypt, being arrayed by Pharaoh in vestures of fine linen ; and again in Exodus ix, 3I, when one of the plagues fell upon it: " and the flax and the barley was smitten: for the barley was in the ear, and the flax was bolled." Job, who is generally supposed to have lived before the Mosaic era, complained that " his days were swifter than the weaver's shuttle." (Job vii, 6). The accuracy of these allusions may be tested by the traveler in Egypt at the present day. The cultivation of the Flax plant, the various processes for separating the fiber and dressing it, and the subsequent operations of spinning and weaving into linen fabrics are depicted, with artistic skill, upon the temples and tombs of Egypt, as freshly as if they had been limned but yesterday, instead of 4000 years ago. It is a remarkable fact that the linen fabrics, in which the Egyptian Mummies were enveloped more than forty centuries ago, are perfectly well-preserved up to this day, showing the extraordinary tenacity and endurance of the Flax fiber, which qualities are not possessed in the same degree, by any other textile. The nations of antiquity which next to Egypt were famed for the products of their looms, were Phœenica, Babylonia, Colchis, Greece, Italy, Germany, Gaul and Spain-the four last named being also Flax-producing regions.

After the fall of the Roman Empire, the linen manufacture underwent a long eclipse in the records of history. Its reappearance in the tenth century, was mainly due to the Flemish. In this century the town of Ypres, in Flanders, was built, and soon became celebrated for its manufacture of table linen, now called "Diaper," i.e. d'Ypres. As early, however, as the seventh century, ladies of rank in England, and even Royal Princesses, had acquired much fame by their skill in spinning, weaving and embroidering rich vestments for the Anglo-saxon clergy. After the Norman conquest there was a constant immigration of Flemish weavers into England. The weavers soon became so important a part of the body politic, that they incorporated in guilds by Royal Charter. The first mention of Irish linen occurs as far back as the thirteenth century; but it was not until the close of the seventeenth century, that it received the impulse which led to its becoming the staple industry of Ulster. The extension of the Irish woolen trade excited the jealousy of the English woolen manufacturers, and in the reigns of Charles II, William III, and Queen Anne, successive enactments were passed by Parliament, prohibiting the export of woolen manufactures from Ireland, except to England and Wales. Not content with these restrictions, in the tenth year of William III, another act was passed, founded on the Report of a Special Committee, forbidding any export whatever from Ireland, of wool or woolen manufactures. The reasons given by the Committee for their 
recommendation were, that the English trade must be preserved, and that the wool and labor being so much cheaper in Ireland than in Great Britain, the English manufacturers could not compete at all successfully with those of Ireland.

The competitors of the Irish linen manufacturers were to be found, not in England, but in France and Flanders; the English statesmen, therefore, had every reason for encouraging the Irish linen trade. (See Crawford's history of Ireland, published in 1783 .) The bigotry of a French Monarch was (next to the ruin of the Irish woolen trade, brought about by the causes enumerated above,) the cause of the prosperity of the linen trade of Ulster. The Huguenots were the most industrious portion of the population of France, and their skill in the industrial arts enriched the nations that received them. A number of French refugees settled in the neighborhood of Lisburn, near Belfast, after the revocation of the Edict of Nantes, A. D., I699, who were skilled in the manipulation of Flax and in the manufacture of linen. The most noted among these exiles was Mr. Louis Crommelin, of St Quentin, France, who was appointed by the British government "Director of the Linen Manufacture of Ireland." His descendants, the Delacherois Crommelins, are numbered among the County families of the Northern Province of Ireland at the present day.

It would be interesting to trace the progress of the Flax industry from that period down to the present time, if the compass of this little work permitted; suffice it therefore to state that Ireland, at the present day, stands pre eminently distinguished for the success and excellence of her Flaxen manufactures, although France, Belgium and Germany still retain a deserved celebrity for the firmness of the fiber and cloth produced by their inhabitants. Russia consumes nearly the same quantity of raw Flax, all home grown, in her factories, as Great Britain, although this does not, by far, suffice for the home demand, immense quantities of linen fabrics beng imported from Ireland, Germany and Austria. The linens and damask goods produced in the districts of Iaroslaw, Kostroma and Archangel, compare very favorably with similar products of other countries much more favored in point of climate, and show what results may be obtained, even under adverse circumstances, by patience and endurance. Austria also produces large quantities of fine and medium linens and damask goods, and carries on a brisk export trade to Russia and Italy. The production of linen fabrics in other countries of Europe besides those named above, is insignificant.

\section{FLAX IN THE UNITED STATES.}

As regards the history and progress of Flax and Flax manufactures in the United States, I canriot do better than to append an extract from the interesting chapter on the subject contained in the Report of the Department of Agriculture for 1877 .

"Previous to the cheapening and general diffusion of cotton fabrics, consequent upon the invention of the cotton-gin and introduction of cotton factories, the production of flax fiber was almost co-extensive with the settlements. Outside of the cities and of the homes of great planters, there was scarcely a housewife or damsel, of whom it might not be said: 'She layeth her hand to the spindle, and her hands hold the distaff.' From a series of papers written between $\mathrm{I}_{78} 7$ and I79I, by Mr. Tench Coxe, Commissioner of the Revenue, and for several years Assistant Secretary of the Treasury, it appears that manufactures from flax and hemp had become an established and very important industry; he enumerates, among articles 'manufactured in a household way,' seines and nets of various kinds, twine and packthread, sailcloth, towcloth, white and checked shirting, sheetings, toweling, table linen, bed-ticks, hosiery, sewing-thread and seine-thread lace. Among the flax products, manufactured in families, in Massachusetts and Rhode 
Island, during the first nine months of $\mathrm{x} 79 \mathrm{I}, \mathrm{Mr}$. Coxe specifies 25,625 yards of linen cloth. The census of ISIO returned $21,211,262$ yards of flaxen cloths made in families; of this, New York produced 5,300,000 yards ; Virginia about 5,000,000 yards; Pennsylvania, 3,000,000 yards; Connecticut, 2,250,000; New Hampshire, 1,000,000; the same census returned a production of 23,952,746 yards of 'blended and unnamed cloths and stuffs,' and $802,7 \mathrm{r} 8$ yards of tow cloth. The census of $\mathrm{I} 860$, after enumerating various subordinate manufactures from flax or flax hemp, adds: Although labor-saving machinery for spinning, as well as doubling, trebling and twisting, was then used to some extent, both by water and steam power, in regular establishments, and some of these had been introduced into familes, this extended manufacture of flax and hemp was almost wholly a household industry."

"In connection with, and largely as a consequence of the uuusual demand for lint and tow to be consumed in multiform fabrics of house manufacture, sufficient quantities of seed were produced not only for house use and internal commerce, but to leave a large surplus for foreign export. In an official abstract of the exports from the United States for the year ending September 30, I70r, Mr. Coxe specifies 58,492 casks of flax seed. This is assumed to be equivalent to 292,460 bushels - that is, over half of the entire product reported for I860, and a fraction over one-sixth reported for 1870. Among the exports of the same year were 18,600 pounds of lint and 6,850 yards of tow cloth ; but as the manufacture of cotton fabrics in factories increased, this universal household industry, which had greatly contributed toward keeping families at home, united and contented, by affording a profitable employment to both sexes and all ages, gradually declined to a vanishing point. One consequence was, that, while the demand for seed was rapidly increasing, production either remained stationary or decreased. No account of the production of flax seed was taken in the census of $I S_{4} \mathrm{O}$, but in $I 850$ the reported product was 562,312 bushels, and the import 667,369 bushels; in 1860 , the product 566,867 bushels and the import $2,754,060$ bushels ; in 1870 , the product $1,730,444$ and the import $4,141,305$. In I875, the import was $3,783,344$ bushels."

The enormous increase in the area devoted to the cultivation of Flax, chiefly for the seed since that period, in the states west of Pennsylvania, has caused a proportionate diminution of the import of Flax seed, which, in the fiscal year ending June 30, I88I, was only 797,910 bushels, chiefly from India. The acreage appropriated to the production of Flax seed in the above states, comprising Ohio, Indiana, Illinois, Missouri, Kansas, Wis. consin, Iowa, Minnesota and Nebraska, in I88 r, being no less thon I, I27,000 acres, the estimate of the quantity of seed produced is about $8,000,000$ bushels, but it must be added that through the heavy rains during the fall months of that year fully 2,000, ooo bushels were a total loss, and much of the crop came in a damaged condition.

\section{A SHAMEFUL WASTE.}

But while Flax seed finds a ready market, and is easily disposed of by the farmer, with whom, as a rule, it is, on that account, a favorite crop, although yielding no profit or at best, only a very small one, a sad tale has to be told of the much more valuable fiber, which, in consequence of the entire eclipse of the "household industry" mentioned above, has come to be considered by the farmer as "a nuisance or an incumbrance," and as such, is either burned, left to rot in the field, used for thatching or allowed to go to waste. It is hard to believe, and yet it is a fact, that probably 800,000 tons of Flax straw is thus annually doomed to destruction, which, if turned to account, inferior in quality though it be, would put from $\$ 4,000,000$ to $\$ 5,000,000$ into the farmers' treasury, but a much larger sum would annually be added to their wealth, if a more careful and more rational mode of 
Flax cultivation were adopted, whereby both the seed and the fiber were saved, and, instead of the present inferior, dwarfish Flaxstraw, a fiber of good quality, suitable for manufacturing purposes, were produced.

\section{OUR GREAT OPPORTUNITY.}

The plea put forward by protectionists that on account of the so called "pauper-labor" in Europe, Flax cannot be grown as cheaply in the United States as in Europe, is entirely unfounded, as the following figures will demonstrate :

The cost of production of Flax in Holland, as communicated by my Rotterdam Correspondents, under date of September 27, I882, is as follows :

Rent of land, including plowing, harrowing, etc.,

Seed $21 / 4$ hectolitres,

Sowing and freight on seed,

Weeding,

Pulling and binding,

Freight by water,

\begin{tabular}{rr} 
Per Hectare. & Per Acre. \\
fl. 300.0 & $\$ 4.00$ \\
38.0 & 6.10 \\
2.0 & 032 \\
25.0 & 4.00 \\
30.0 & 4.80 \\
35.0 & 5.60 \\
\hline fl. 4300 & $\$ 68.82$
\end{tabular}

Totals,

(One hectare is equal to about $2 \frac{1}{2}$ acres, and one florin is equal to 40 cents United States currency.)

The cost of production of Flax in France, communicated by the President of the Socièté d'Agriculture of Calais, France, under date of October 7, 1882, is as follows :

Preparing the land, three plowings, harrowing, etc.,

Per Hectare. Per Acre.

Seed $21 / 2$ hectolitres,

Weeding,

Pulling and binding,

Rent of land,

frs. I50.0 \$12.00

Other small expenses,

$$
\begin{array}{rr}
62.0 & 5.00 \\
-\quad 80.0 & 6.00 \\
50.0 & 4.00 \\
125.0 & 10.00 \\
18.0 & 100 \\
\hline \text { frs. } 485.0 & \$ 38.00
\end{array}
$$

(One franc is equal to 20 cents ; the hectare is the same measure as in Holland).

The following is the cost of production in Ireland of one acre of Flax, as stated by Mr. Wm. Charley, Seymour Hill, near Belfast, viz :

Two plowings

Grubbing and harrowing,

Twice picked of weeds,

Harrowing seed and rolling,

Weeding, -

Preparing rushes and ropes,

Pulling,

Seed, one barrel,

Rent and taxes,

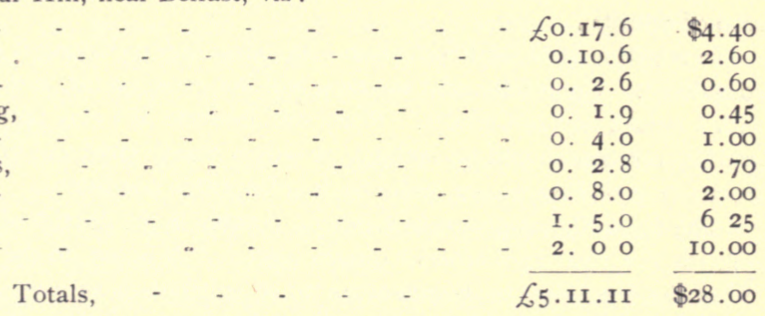

The cost of Flax production in Illinois, according to the Report of the Illinois State Board of Agriculture, in various counties, is as follows :

Use of land,

Plowing,

Harrowing,

Planting,

Seed, -

Cutting,

Stacking,

Threshing,

Marketing,

\begin{tabular}{crr} 
Hamilton Co. & Cook Co. & Kane Co. \\
$\$ 2.00$ & $\$ 3.25$ & $\$ 4.50$ \\
0.75 & 1.50 & 1.30 \\
0.25 & 0.25 & 0.25 \\
0.40 & 0.25 & 0.30 \\
0.60 & 1.35 & 1.00 \\
0.50 & 0.60 & 0.50 \\
3.30 & 0.50 & 0.80 \\
1.00 & 0.80 & 3.50 \\
0.15 & 0.60 & 1.25 \\
\hline 5.95 & $\$ 9.10$ & $\$ 13.10$
\end{tabular}


I have given the highest, the lowest, and a medium calculation of the cost of production in this state, but the average may be taken as $\$ 10.00$ per acre, and thus it will be seen that even doubling this amount, in order to make up for additional labor and larger outlay for sowing seed, we are still much below the lowest rate at which Flax is raised in Europe, while the cost of Flax production in France is twice as high, and in Holland three times as high as ours. We are, therefore, undoubtedly, in the most favorable position to compete with any country in the world and need no "protection" for raising Flax, any more than for growing wheat, corn, cotton, or any other of our staple crops. All that is needed is to imitate our European competitors in the care they bestow on the Flax crop as suggested in the following pages on this subject, and most remunerative harvests will surely be the reward.

\section{F'LAX CULTURE.}

\section{SOIL.}

Flax culture requires very careful preparation of the land; deep tillage and thorough pulverization being essential to success. By careful attention to these prime requisites Flax may be profitably grown on almost any soil, although all are not equally adapted to this crop. The best soil is considered to be a firm sandy loam; or a dry mellow loam with a clay subsoil, but this must not be too compact, and by all means it should be well drained. Flax will not do well if the land be wet, nor upon heavy clay soil unless thoroughly underdrained, well pulverized and enriched with manure. It is no more reasonable to expect to raise a good crop of Flax from a poor, wet, half-cultivated soil, than a good crop of wheat.

In selecting land for Flax culture, the advantage of having it smooth and level should be considered. Upon hilly land the crop will not grow evenly, nor can it be readily harvested with a mower and self-binder. Peaty soil destitute of a clay bottom, also sandy land with a gravelly bottom, should be avoided, as only a scanty yield and inferior fiber can be expected from a crop of Flax grown under such unfavorable conditions.

The finest Flax is grown in Belgium, notably in the district of Courtray. Regarding the soil, the English Agricultural Gazette says: "It is not to the natural fertility of the soil "that the fine crops in Flanders are to be attributed, as a very brief inspection of it will " suffice to show. We have before us a sample of soil taken from a celebrated Flax dis" trict, at which we do not hesitate to say many an English farmer would turn up his nose " as beneath his notice and unworthy of his cultural cares. It is to the careful working of " the soil, the unstinted supply of manure, of which the quality and mode of action on the "soil and plants is a matter of careful and anxious study; to an equally careful attention to " the quality of the seed and the properties of the plant ; and last but not least, by carrying " out a well-considered system of rotation, that the Flemish farmer owes his success in Flax "culture."

The above paragraph embodies the secret of successful and lucrative Flax culture, and I commend the hints given therein to the serious consideration of American growers of Flax. 


\section{ACREAGE TO SOW.}

The next point to consider, and an important one, is as to what extent, or in what proportion the farm should be devoted to Flax raising. Of course this cannot hastily be determined, nor can an inflexible rule be laid down. Much depends upon the farmer's ability to thoroughly work the land, and keep it in the high state of cultivation which is really the basis of successful Flax farming.

There is no farm crop for which the soil needs so thorough preparation as that required for Flax ; nor is there any crop that will give better returns for the cost and labor of fertilizing and pulverizing the soil, and keeping it clean of weeds.

The farmer, therefore, must needs count the cost himself, and with his eyes open to the necessities of the case, use his best judgment as to the acreage he can profitably devote to the Flax crop, in order to secure the highest yield both of fiber and seed.

\section{ROTATION.}

Neglect of the important matter of rotation has been to a great degree the cause of the diminution in yield per acre, and consequently of disappointment to the farmer in raising Flax. This crop should never be grown successively upon the same field. There should be an interval of from 6 to Io years between crops, so that the land under cultivation may regularly receive back from the different manures applied a portion of the special nutritive elements of ' which it was depleted by the Flax, and after the interval specified be enabled to abundantly feed another similar crop without any artificial recuperation of the soil.

If, before sowing Flax again in the same field, some 7 or 8 years are suffered to pass by, it is reasonable to expect a good crop; but the shorter the interval between the crops the less is the second to be counted on for a fair yield either of seed or fiber.

In the West and Northwest Flax is frequently sown upon sod land, and although heavy crops are generally produced, the practice is to be discouraged. One objection is the difficulty of bringing such land into a satisfactory condition of tillage. Another is the damage to be apprehended from the cut-worm, which attacks Flax as well as other grains sown in sod land. It were much better to let the Flax follow potatoes upon such land. Too frequently it follows wheat or oats, grown after a root crop the previous year, which only answers where the condition of the land is maintained by extra manuring. Flax should never follow turnips; it has been shown by repeated experiments in Europe that such a rotation is sure to result in failure.

The diagram given below will show at a glance a system of rotation which if followed, allowing for the necessary modifications to adapt it to different farms, will maintain the land in a fertile condition. It will be observed that the crop of Flax occupies the same ground after the lapse of 9 years; also, that it never follows turnips.

The system commonly known as the four-course rotation, in which Flax may be included, will doubtless keep up the fertility of the land, but instead of putting all the land into wheat that had been in a root crop the previous year, it would be preferable to make a division, and sow two-fifths to Flax, and three-fifths to wheat.

What would really re-invigorate the production of this valuabie crop would be the reduction of the acreage allotted to wheat, and the substitution of Flax. 
DIAGRAM.

\begin{tabular}{|c|c|c|c|c|}
\hline YEARS. & \multicolumn{3}{|c|}{ CROPS. } & YEAR. \\
\hline I & Turnips. & \multicolumn{2}{|c|}{ Potatoes or Corn. } & $\cdot \cdot \cdot$ \\
\hline 2 & \multicolumn{3}{|c|}{ Wheat or Oats. } & Ist \\
\hline 3 & \multicolumn{3}{|c|}{ Clover or Grass. } & $2 \mathrm{~d}$ \\
\hline 4 & \multicolumn{3}{|c|}{ Rye, Oats or Barley. } & $3 d$ \\
\hline I & \multicolumn{3}{|c|}{ Potatoes or Corn. Turn } & $4^{\text {th }}$ \\
\hline 2 & Flax. & \multicolumn{2}{|c|}{ Wheat or Oats. } & $5^{\text {th }}$ \\
\hline 3 & \multicolumn{3}{|c|}{ Clover or Grass. } & 6 th \\
\hline 4 & \multicolumn{3}{|c|}{ Rye, Oats or Barley. } & $7^{\text {th }}$ \\
\hline I & Turnips. & \multicolumn{2}{|c|}{ Potatoes or Corn } & 8 th \\
\hline 2 & \multicolumn{3}{|c|}{ Wheat or Oats. } & $9^{\text {th }}$ \\
\hline
\end{tabular}

The above is introduced merely for the purpose of illustrating the judicious rotation of crops under cultivation. It is assumed that a portion of the farm is undergoing the necessary renovation by lying in pasture for some years. No arbitrary rules can be laid down for rotation. The intelligent farmer should be best qualified to judge of the proper course to follow upon his own farm, the peculiarities of which he is fully acquainted with. The suggestions here made, however, may serve to guide him in this respect.

\section{PREPARATION OF THE SOIL.}

Weeds may properly be regarded as the worst enemy of the Flax crop. They not only appropriate from the soil much of the nutrition required by the Flax plants, - which is a great injury even when the crop is raised solely for the seed-but they are chiefly injurious when Flax is grown for the fiber for the reason that in harvest-time the flax stalks get so entangled with weeds that it is impossible to separate them, and thus the value of the straw is seriously impaired. The necessity of clean culture, therefore, is at once apparent.

The preparation of the land intended for Flax must be governed mainly by the character of the soil. A light plowing immediately after harvest is essential upon all soils; but if the ground be heavy and stiff it should be laid in ridges before winter sets in, and so remain until some two or three weeks before sowing time, when it should be deeply plowed. Light soils may have their last plowing before the ground is frozen up for the Winter. Medium soils may require a second plowing, which should not be done less than a month previous to sowing; this second plowing of medium and heavy land should be shallow, not exceeding four inches in depth. The soil should be sufficiently loosened and mellow to allow the roots to penetrate about $1 / 2$ as far into the ground as the stem reaches above.

Strong soils, and such as are coarse and wet, are usually cross-plowed before Winter. Where Flax follows clover the land which has been enriched with farm-yard manure or peat ashes receives in Autumn a like quantity of the same manure, which is covered with the plow and well harrowed to make the soil mellow. In Spring a vigorous harrowing is given, and the seed is sown. 
When Flax is to be sown in potato ground, it need only receive one shallow plowing, say 4 inches deep; and if the soil be light this should not be done until a month or six weeks before sowing But if the soil be heavy it would be beneficial to have it done earlier so as to expose the ground to the pulverizing action of frosts.

When seed-time arrives, should such weeds as dock, sit-fast, couch grass, etc., appear, they should be extirpated previous to harrowing. After this is done harrow thoroughly-if in ridges, lengthwise only; if level, cross-harrow also. The objection to cross-harrowing when the land lies in ridges is that it drags soil into the furrows and leaves a loose bed for the seed. When the land is well drained, or naturally dry, I would recommend flat cultivation, by which more even growth is secured. This is especially important when Flax is grown for the fiber. Where there are furrows in the field, that portion growing along these depressions will not be as strong and vigorous as the rest of the crop.

It is well to keep in mind that the important thing in preparing the soil is to have a fine, deep, dry and clean bed for the reception of the seed.

Depth of tillage is a matter of more moment in Flax cultivation than is generally supposed. In sustaining so tall a stem, and providing the varied elements so essential to the healthful growth of the plant, the roots have a most important function to perform. If given opportunity they will penetrate the soil to a considerable depth, and provide bountifully the nourishment which the plants require. But if cramped and restricted by a compacted, impenetrable soil, the crop will plainly show that it is half-starved. The Belgians say that Flax has roots that go as deepinto the soil as the stem grows high above the ground. The soil should be so open that there may be free percolation of water, the roots being very fibrous and extending both laterally and vertically to a considerable distance.

The extent to which the soil should be pulverized, it is proper to state, depends greatly on its peculiarities. On light and medium soils excessive pulverization does actual injury. After such have received a deep plowing in Autumn, and when necessary, also, a shallow plowing in Winter, a moderate harrowing will be amply sufficient to make it a good seedbed at sowing time. Pulverizing such soils to any great depth renders the chance of a good crop of Flax extremely doubtful, unless, indeed, the season should prove an exceptionally wet one. Heavy land, on the contrary, will bear any amount of pulverizing; there is no danger of overdoing it.

\section{MANURES.}

The use of green stable manure is to be avoided, principally on account of its containing weed seeds which have not yet germinated. Ashes from the burning of heaps of brush and rubbish are highly beneficial. In Belgium, where the best Flax in the world is produced, preference is given to liquid manure, collected mainly from the cow house and stables, which is allowed to ferment in cisterns provided for the purpose. With this material oilcake is mixed. The quantity of this manure varies from 100 to 300 hectolitres per hectare, (which is equivalent to from 9 to 27 gallons per acre.) Solid manures are only used after being thoroughly composted and rotted. It is also of importance that the manure be applied evenly to the land. Whenever the manure is distributed unevenly, the crop exhibits irregular patches which are more vigorous than the average, and therefore the product is of unequal length, which is an injury to the fiber.

One method of avoiding the difficulty is to apply the manure in liberal quantities to the preceding crop, applying none to the land the season of the Flax crop. Another is to put on the manure in Autumn or Winter, so that it may become thoroughly amalganated with the earth by the action of the elements previous to the sowing.

Commercial fertilizers have the advantage of being free from seeds of worthless and noxious plants, and without doubt, can be used on Flax with profit; but this class of 
manures should be used with caution and with an accurate knowledge of the constituents of the land to which they are applied as well as of the fertilizer itself. The prudent farmer will, so far as practicable, produce upon his own farm the manures necessary to keep up its fertility.

\section{SEED.}

The selection of seed is a matter which is entitled to special consideration. Great care should be exercised in this direction, as the success of the crop depends to no small extent on the quality of the seed.

Flax seed is considered of good quality when it is bulky and heavy, the faces of each seed being equally plump and convex; color a bright brown, uniform; should sink in water ; be easily combustible, burning with clearness and rapidity. The inside, when broken, should be of a light yellowish-green color, should have a sweet taste and be very oily. Good seed, too, is very even in its quality, and free from all mixture with other seeds, especially of weeds.

Only fresh seed is suitable for sowing. If it is more than two years old, it should always be tested as to germinating power before regarding it as wholly reliable. This may be done in the following manner: Place a few grains of seed upon flannel cloth stretched out smoothly, and kept moist, in a warm room. If the seed germinates uniformly in about twenty-four hours, it may be depended on as good; if, however, the germination is delayed several days, taking place unequally as to time, the seed should be rejected as unfit to sow.

Another method of testing the vitality of Flax seed is given by Mr. Todd, the writer of a recent prize essay: "To test Flax seed select a few grains and sprinkle them " between two thin pieces of sod laid earth sides together, and put them on a shelf in the " kitchen where they must be kept, warm, and not allowed to dry. In a few days every " seed that has not lost its vitality will germinate. Then by counting them we readily " ascertain what proportion is good."

Care should also be taken to clean the seed of all weed seeds, and other impurities which will otherwise infest the land, and cost much labor and expense in weeding them out if ever got rid of. The cleaning may be effected by a wire sieve, twelve meshes to the inch, costing about seventy-five cents.

Right here let me say, that none but the very best and purest seed should be procured for sowing. It is a false economy and most wretched management unworthy the intelligent farmer of the present period, to buy low-priced seed in order to save a few dollars, thereby running the certain risk' of getting a crop which will barely cover the cost of production.

So far we have considered only the general characteristics of good seed, and ways of testing its vitality. But it is necessary to go much farther than this. It has become a question of vital importance whether our American grown seed must not, after all, be replaced by a foreign product, which shall yield far better results than have of late years been obtained in this country.

Hitherto, Flax has been grown in the states west of Pennsylvania chiefly, if not exclusively, for the seed. Naturally it might be expected that the yield would be abundant and certainly give a moderate profit above the cost of production. But such has not been the fact. Fifteen years ago the yield of the Flax crop was from I2 to $\mathrm{I}_{5}$ bushels of seed per acre, while at the present time it is from 5 to ro bushels, giving an average of 7 to 8 bushels per acre, or only 50 per cent. of the former yield. The causes of this extraordinary decline are not difficult to discover. They are to be found ( $\mathrm{I}$ ) in careless and improper cultivation, and (2) in the very inferior quality of the seed sown, the great bulk of which is entirely unfit for the purpose of reproduction. 
While the first of these causes can be removed through more careful husbandry, the second demands, imperatively, a total renewal of seed for sowing. Flax seed has become completely degenerated. Since its first introduction into the United States it has never been renewed, save, perhaps, in a few localities to a limited extent, and the result of long continued careless culture is seen in the present diminished yield which is so exceedingly unsatisfactory and mortifying to every intelligent American farmer cognizant of the facts.

Nor is it alone in quantity of seed produced that the degeneracy in Flax culture in America is exhibited. The oil-producing quality of the seed has also declined to a very serious extent. Oil crushers assert that Western seed produces one-third less oil than that imported from Bombay and Calcutta, and hence its price is only about one-half of that paid for seed imported from British India.

In order, therefore, to rehabilitate Flax culture in this country, bringing it up again to the state from which it has fallen, both as regards its yield per acre and its oil-producing quality, so that it may successfully compete with the foreign product, placing it on a par as regards its market value, it has become indispensable to sow entirely new seed which has been grown in a wholly different soil, and with special reference to this object.

Of the foreign seeds which have stood the test of many years experience, and have given the most satisfactory results, the Dutch and Russian seeds stand pre-eminent. In those European countries where Flax raising has been a chief industry from time immemorial, and where it has been brought to a high state of perfection, notably in Ireland, Belgium, Holland, Germany and France, fresh seed is annually imported from those countries which produce the best seed for the purpose. Ireland, for example, imports every year the entire quantity required for sowing, from Russia and Holland. The total quantity imported in I 880 and I88I, respectively, was $3 \mathrm{II}, 86 \mathrm{I}$ bushels, and the total acreage appropriated to Flax in the years named was 157,534 and 147,085 acres respectively, thus allowing about two bushels of seed per acre.

Holland, whose seed is highly esteemed for its superior quality and great purity, likewise imports her sowing seed from Russia and sells her own seed at remunerative prices to her neighbors. Belgium, France and Germany annually import Dutch and Russian seed for sowing. Thus a regular and constant interchange is taking place in those countries. Experience has demonstrated that by this means the best crops are oroduced both in respect to seed and fiber.

It is therefore a matter of vital importance, especially in the western states, that there should be a radical change inaugurated in the character of the Flax seed used for sowing in this county. This cannot be done too soon. Thus only can Flax culture be reclaimed from the lamentable state of degeneracy into which it has fallen.

The present mode of cultivating Flax for the seed only is greatly to be deprecated, and I would commend the following extract from the words of a competent writer on this subject, to the serious consideration of all who are interested in Flax cultivation.

"The pursuit of the crop for the seed only, will never secure the firm establishment of "Flax culture. The additional inducement of a production of the valuable fiber is neces"sary to make Flax culture a leading farm interest. Crops of Flax seed may be grown "with poor cultivation and scanty sowing when the straw will be worthless from its coarse" ness, and the weakness of the lint, and from the admixture of grass and weeds. To ob" tain Flax of the highest value for the seed only it is essential that the cultivation be con" ducted with special reference to the production of the largest yield of good fiber in the "straw. This conclusion is justified by the fact that the average product of Flax seed per " acre in those districts in the Eastern states where Flax is grown more especially for the "lint, is greater than at the West where the seed only has been the object of cultivation, 
" while at the same time the quality of the Eastern seed is superior. The carelessness of " management attendant upon growing this crop for the seed, in connection with thin sow" "ing, tends to deteriorate the quality of the Flax seed for oil making, as well as for the "production of lint."

The foregoing, although written twenty years ago, is applicable even with greater emphasis, to the present state of Flax culture in the West, than at the time it was written, and the conclusions drawn by the writer are proved to be literally correct, and justified by facts easily verified by any one who is interested to examine the statistics.

It is important that the misconception so widely prevalent, that seed must be sown thinly when Flax is grown especially for its seed product, should be removed. Let it be fully understood that it is by no means necessary to neglect the fiber in order to obtain the largest yield of seed, and this of good quality.

It only requires careful and intelligent culture to place the Flax crop upon a satisfactory basis, and render it in the near future one of the most remunerative of all farm crops.

\section{HOW TO SOW.}

After the land has been carefully prepared, (according to the hints already given in this paper,) and after removing all the stones (except the small ones which will do no harm) it would be well to give it a final harrowing and rolling before putting in the seed. The object of this is to have the surface of the ground as smooth and level as it can be made, so that the Flax may get an even start, and grow uniformly, in order that harvesting may be facilitated (if a Mower and Self-binder is employed), and also to secure the greatest length of straw possible by cutting low to the ground.

If the sowing is upon an uneven surface, where there are lumps, clods, furrows and holes, much of the seed will be covered too deeply, and consequently the growth of the straw will not be uniform, nor will the seed mature at the same time. If there are no lumps, however, the roller need not be used. But the ground should be gone over with a harrow having numerous small teeth. Where the soil has been cultivated as it should be for the preceding crop of Indian corn, potatoes or barley, the surface will be as mellow and free from lumps as a neatly prepared carrot bed. On such soils, with selected seed, Flax will grow from 3 to + feet in length, the seed will be of superior quality, and the lint will be heavy and of good length.

Sow on the rolled surface, and while it is still fresh, because Flax, like other seed, will more quickly germinate under such conditions than if put into soil that has lain undisturbed for a number of days. The soil should not be at all adhesive or sticky when the sowing is done. A favorable time is when the weather is calm and dry, if shortly after a shower all the better, when the lumps of dirt will crumble at a very slight touch, and the entire surface is friable and mellow. Then the seed, germinating in a few days, will get ine start of weeds, and easily keep the ascendancy throughout the period of growth. By this means much weeding will be saved, the fiber be more abundant, the seed of better quality, and the yield of both products be greater.

As Flax seed is much more difficult to sow than most other kinds of seed on account of being so very slippery, it is very important that, if the sowing be done by hand, an experienced sower should be employed. It is of prime importance that the seed be sown evenly, and doubtless this can be accomplished more readily and surely by the use of a "Broadcast Seed Sower," one of the inventions of late years,* which will ensure more even sowing than

* "Cahoon's Broadcast Seed Sower" is especially recommended for this purpose. Price $\$ 6 . \infty$. For sale by Hiram Sibley $\&$ Co. 
can be done by hand. Another advantage offered by these implements is the large acreage which can be sown in a short time. The saving in labor thus secured is very large, and there is a material saving also in the quantity of seed required. When, however, hand sowing is to be employed, especial care should be taken to sow as evenly as possible, the sower proceeding with a regular step, taking small tight handfuls, and casting the seed with regular throws high and fearlessly, allowing each cast to slightly overlap the preceding one. If not careful the slippery seed will escape in the backward swing of the hand, and thus not only waste, but render the seeding irregular. Some cultivators advise soaking the seed in tepid water for two or three days, and then rolling same in gypsun or plaster. This remedies the slipperiness, and the gypsum is beneficial in effect upon the germinating seed.

It may be suggested that if the farmer intends sowing a large acreage to Flax, it will be well not to do all the sowing at one time, but at an interval of a week or ten days, in order that time should be given to harvest before part of it gets over-ripe.

\section{COVERING SEED:}

The seed should not be covered too deeply. One inch of soil is suficient, and it should be as uniformly of this depth as possible. Therefore, a light, fine-tooth harrow, is best adapted to this work. Some very careful cultivators do not allow a team of any kind to be driven over the land after the seed has been put in, but draw a brush harrow, by hand, over the soil, regarding this the preferable wa* of covering the seed. Such a harrow can readily be made by inserting the butt ends of brush (smail branches of trees) about two feet long in holes bored in a piece of scantling, which should be about five feet in length. To this scantling shafts or handles may be fitted, so that the harrow can be drawn by a man or boy. With this "harrow" several acres can b? "brushed in" in a day. It would be well to also cross-harrow the land with this brush so that no ridges be left, and the land may lie uniformly smooth. The effectiveness of such a brush harrow may be increased by adding to its weight a few billets of wood fastened to the scantling which holds the brush in place. Rude as is this novel iraplement, it will be found most competent for the purpose of properly covering the seed. Where the acreage is large, however, a light harrow drawn by horses will of course be the most practicable.

\section{WHEN TO SOW:}

Owing to the wide range of climate in which Flax is (or may be) cultivated in the United States, no invariable rule can be given, much depenüing on the peculiarities of the season as well as geographical position.

As a matter of course Flax may be sown much earlier in Missouri or Kentucky than in Minnesota, Wisconsin or Dakota, for there would be much less risk in the section first mentioned of late Spring frosts, which frequently do serious injury to the tender plant, causing it to branch, to the great detriment of the crop. The Flax grower is therefore to be guided by his own experience and observation in his own section as to the right time for seeding. A few suggestions, however, may be of service in determining the point. Sow after the soil has become settled and thoroughly warmed by the influence of the sun, when weeds and grass have well started, and the trees begin to unfold their leaves. If sown too early much of the Flax is liable to be stunted; late frosts will injure it more or less, and weeds are sure to get the start of the plants unless extra pains have been taken in clearing the soil of their roots beforehand. In the middle wheat belt of the United States the average time of sowing is from the $15^{\text {th }}$ to the 20 th of April, in ordinary seasons, and in favorable weather. 


\section{HOW MUCH TO SOW.}

The quantity of seed will depend on the object for which it is sown, the quality of seed, and its kind. Of foreign seeds the Dutch produces a finer fiber than Russian, but it is also affected by the quantity sown. A finer fiber is produced when thickly sown than if the sowing be thin. The effect of this sowing is that the plants not being crowded branch freely, and produce a greater quantity of flowers and seed to each individual plant than when growing closer together. The yield per plant is unquestionably greater for thin sowing, but the product per acre is the important thing, especially when the quality is considered, and also the largely increased quantity and value of the fiber.

Our Western farmers who have been growing the crop, hitherto, exclusively for the seed, sow but $1 / 2$ bushel or at most $3 / 4$ bushel per acre; but in the eastern states, on poorer soils, where the farmers desire to secure crops both of seed and fiber, it is found that they obtain a much larger amount of seed per acre than the average in the West, and this, too, of superior quality.

In Europe two bushels is an average allotment for seeding an acre, producing a fine lint, and after harvesting from the crop 20 bushels of seed. It has been found that in the thoroughly cultivated and highly manured fields of the Flax region of Belgium, the largest quantities of seed-often as much as $3 \frac{1}{2}$ bushels to the acre-are sown with the best results. In that country, as also in France, it is a common practice to sell the crop standing in the field before harvesting, to the "Linier" or Flaxman, who relieves the farmer of its further care when it has matured.

I would, therefore, recommend that even where the production of seed is the only object of cultivation, at least one bushel be sown per acre. This would tend toward the improvement of Flax culture in the United States, especially in the West, and the results would be immediately beneficial.

\section{WEEDING.}

Whatever weeding may be found necessary after the crop has come up, should be done with as little treading upon the tender plants as possible. It is important that this be attended to when the soil is not too dry, as there is risk of disturbing the roots to their injury. It were better to leave the crop altogether unweeded, unless it can be done when the ground is moist.

\section{WHEN TO HARVEST,}

When the lower part of the stems begin to turn yellow, and the leaves fall off 8 or Io inches from the ground; when the seed capsules are formed and the seeds begin to change in color from green to pale brown ; then is the proper time for harvesting the crop.

Discriminating judgment is required that no mistake be made on this point. If harvested prematurely the fiber will be weak, and there will be loss both in quality and quantity. If the Flax be left standing until the seed be fully ripe the fiber will be coarse, brittle and diminished in quantity. As for the seed, experience has amply demonstrated that most seeds, though not quite mature when gathered, ripen fully afterwards provided they are not separated (until completely dry) from the plant, in which the sap still contributes to the further nourishment and perfecting of the seed.

If in sowing the crop the acreage has been divided by an interval of several days, as has been recommended, harvesting in good condition will be easily accomplished, as that portion which ripens first may be taken care of before the balance of the crop has matured, and so no part of it will be over-ripe. 


\section{HOW TO HARVEST.}

Harvesters (with Twine binders) have now come into general use in this country, and may be so adjusted as to cut the Flax quite close to the ground. This should be done in order to secure the largest quantity of fiber, a matter which has hitherto failed to receive the consideration its importance demands-at least in the West.

Pulling the Flax, as is the mode in European countries, is in this country out of the question, both on account of the high price of labor, and the large acreage sown. But our harvesting machinery has been brought to a high degree of perfection, and does the work of cutting very satisfactorily, and at the same time binds the Flax in convenient sheaves or bundles ready to be stooked for drying thoroughly before removal from the field.

\section{DISPOSITION OF THE CROP.}

We now come to the most vital question of all, as regards the Flax interest in the United States. What shall the farmer, having harvested his Flax crop, do with it? If he can only thresh it out with the ordinary threshing machine, by which the fiber is torn into small shreds, and thereby rendered unfit for the best manufacturing purposes, he suffers great loss. The value of the fiber is reduced from $\$ 20.00$ and upwards, to about $\$ 3.00$ or $\$ 4.00$ per ton, being only fit for making coarse bagging, twines, upholstery tow, etc. What better can he do? Perhaps some would answer: Let him put his fiber into merchantable shape, by first "rippling" (or removing the seed), then "retting," "scutching," etc. But this is wholly impracticable. The farmer is a producer, not a manufacturer. He should not be burdened with the various complicated manipulations necessary to prepare the Flax fiber for market. Hitherto this apparent necessity has been a chief obstacle to the development of the Flax industry of the western states, and the indirect consequence has been the absolute waste of hundreds of thousands of tons, annually, of this valuable raw material. It is patent to every intelligent mind that the Flax grower has no time to devote to even crude and preliminary manufacturing operations, even if he had the special knowledge requisite.*

What is imperatively needed, then, is a system by which the labor connected with the Flax industry be divided. On account of the high price of labor in this country, the preparation of Flax fiber requires the employment of expensive machinery, and the erection of

*The following extract from a letter published in the IRISH FARMERS' GAzETTE, contributed by an intelligent writer from the vicinity of Belfast, which is the great center of the Flax and linen industry, points out the disadvantages of the system hitherto followed in Ireland and elsewhere, and advocates a radical reform :

"The present system of retting and scutching Flax is not at all what it should be. I do not suppose there has been any improvement in either department for the last 30 or 40 years-the same slovenly routine year after year; good Flax straw spoiled from being steeped too much or toolittle, or from being left too long on the grass; then when brought to the scutch-mill it is hurried through, because scutchers are paid by the stone, and, of course, the more they can do in the day the better for them. The farmers are persuaded that the better the yield from the scutch-mill the more profitable for them, while the fact is that in a valuable fiber like Flax the more carefully it is handled and the cleaner it is left the better it will pay the owner. $\quad * \quad * \quad * \quad * \quad * \quad$ The system, in my opinion, is altogether wrong.

"Farmers should only be required to grow Flax and should have nothing to do with the steeping of it. That is a delicate process, requiring a practical scientific knowledge and careful attention which could not be expected from farmers generally.

"In Ireland we can raise Flax straw quite equal to that grown on the Continent, which brings 15 to 20 per cent. more than ours, but where we fail is in the steeping and preparation. I believe the Irish Flax trade will never be satisfactory till the Flax can be bought from the grower and the retting and scutching carried on the year round. It would almost revolutionize the linen trade in Ireland. We would have Flax prepared for sale with a regularity in color and quality unattainable now." 
factories or Flax mills. The Flax, including the seed, should be purchased from the farmer by the mill which prepares the fiber for market. This should be equipped with the best machinery and provided with a force of competent operatives, trained to the work and fully acquainted with the most approved methods of retting, etc.

By such a system the cultivation of Flax can be made a leading and remunerative branch of American agriculture, and at no distant period there would be in successful operation all over the country (especially in the western states) large industrial establishments for spinning and weaving the Flax fiber in the manufacture of linen fabrics, thereby effecting a saving of over $\$ 25,000,000$, which we now annually send abroad for this description of merchandise, to enrich foreign nations.

No country in the world is in a position to rival the United States in respect to climate, soil, and many other advantages which enable us to compete in Flax production with the most favored nations, and there is no reason why Flax products should not become, within a comparatively brief period, one of our most important articles of export. All we have to do in the attainment of this desirable end, is to abandon the present slovenly system of Flax husbandry, and adopt the careful and pains-taking methods of cultivation of our European competitors. The introduction of a system comprehending the erection of Flax mills in the principal Flax growing centers would be a powerful stimulus to farmers to improve their present mode of culture in order to obtain remunerative prices for their Flax crop, and encourage them to devote to it the care and attention it so richly deserves.

\section{IS FLAX AN EXHAUSTIVE CROP?}

The objection is frequently urged against the cultivation of Flax that "it is an exhaustive crop." Of course it is true that Flax exhausts the soil that feeds it to some extent, so also does almost every other crop. But that it is more so than others is a statement not supported by the facts; in reality, it is much less exhaustive than most of our other staple crops, as I shall show by the testimony of competent judges.

Sir Robert Kane, of the Dublin Royal Academy, says : "Every farmer is aware that crops exhaust the soil ; that the plants take out of the ground a number of materials, and that it is necessary to restore similar materials to the soil, in order to keep up its fertility ; therefore, the manure which the farmer puts in with or before his seed, is in a degree the raw material of which the crop is made. It is just as much a part of the plant as the seed itself. When the farmer sells and sends away his grown crop to be used for food, as in the case of wheat, oats, and potatoes, he thereby sends away and sells the essence of the manure which he had put into the ground; and as he thus gets paid for the manure which he has exhausted, he must put in as much more for the next crop, which is to be dealt with in the same way. Now, in the case of Flax, there is the important peculiarity that it is not eaten, and hence does not return to the land any manure in the ordinary way, while it takes out of the soil just the same materials as oats and potatoes (though not by any means the same quantity), so that it is indeed quite an exhaustive crop if we look only to the growing of it. But the Flax differs from other crops in this, that the value of oats or potatoes, and all food crops depend upon what they take out of the ground, whilst the valuable part of the Flax is the fine fiber or thread, which has taken nothing out of the ground.

If you burn a bundle of Flax stalks it will leave behind a large quantity of white ashes, which consist of the different substances which the plant took out of the ground; but if you burn a bundle of well-dressed Flax it will leave no ashes. Their substance has been carried off with the waste part of the plant in the steeping and scutching. This is thrown away, and yet they are materials which the plant has appropriated from the soil, and which should be given back to the land in order to keep up its fertility. 
To the practical farmer it is, therefore, of the greatest importance to recollect this principle, that the fiber or valuable part of the Flax is not formed by exhaustion of the soil, but the materials which the Flax plant takes out of the land are all found in the steepwater and the chaff; and that if these be returned to the earth they will restore its fertility, and that thus the Flax crop may be rendered one of the least injurious to the ground, and most remunerative to the farmer."

\section{COMPOSITION OF PLANTS.}

Following are analyses, made by Sprengel and Sir Robert Kane, of both Flax seed and the entire Flax plant, showing the relative quantities of inorganic matter contained in Ioo parts of their ashes:

\begin{tabular}{|c|c|c|}
\hline & $\begin{array}{c}\text { ENTIRER } \\
\text { FLAX PLANT. }\end{array}$ & FLAX SEED. \\
\hline Potash..... . . . . . . . . & II .78 & I 7.59 \\
\hline 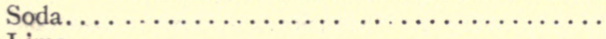 & II .82 & 6.92 \\
\hline 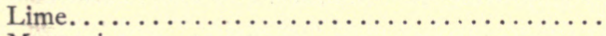 & 14.85 & 8.46 \\
\hline 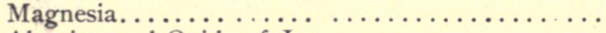 & $9 \cdot 3^{8}$ & 14.83 \\
\hline Alumina and Oxide of Iron $\ldots \ldots \ldots \ldots \ldots \ldots$ & 7.32 & I. 25 \\
\hline Phosphoric Acid,$\ldots \ldots \ldots \ldots \ldots \ldots \ldots \ldots \ldots \ldots \ldots$ & 13.05 & 36.42 \\
\hline Sulphuric Acid $\ldots \ldots \ldots \ldots \ldots \ldots \ldots \ldots \ldots \ldots \ldots$ & 3.19 & 2.47 \\
\hline Chlorine $\ldots \ldots \ldots \ldots \ldots \ldots \ldots \ldots \ldots \ldots$ & 2.90 & 0.17 \\
\hline 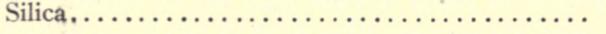 & $25.7 \mathrm{I}$ & $10.5^{8}$ \\
\hline Totals ... & 100.00 & 98.69 \\
\hline
\end{tabular}

Assuming the yield of an acre to be two tons of straw and ten bushels of seed, each bushel weighing $56 \mathrm{lbs}$., the quantity of inorganic matter abstracted from the soil will be :

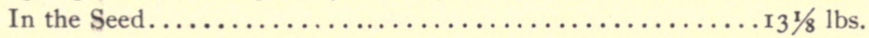

In the Straw.........................

Total .......................... $\overline{783 / 8}$ lbs.

Prof. Hodges, Queen's College, Belfast, who has devoted much time to study of the Flax plant, writes that "it is an exhausting crop (like every other plant that is cultivated for food, " or for its utility in the manufacture of clothing, or, indeed, iike every weed that springs up " along the highway), in that it takes certain matters from the soil. When only part of the " plant, like wheat, for instance, is sent to market, it is clear that only a part of the matters " of the soil is lost to the farm, and therefore its exhaustion is delayed."

But he claims that Flax is not as exhaustive as some other crops, and gives the following table showing the amount of phosphoric acid and alkalies contained in Ioo parts of the ash of several plants:

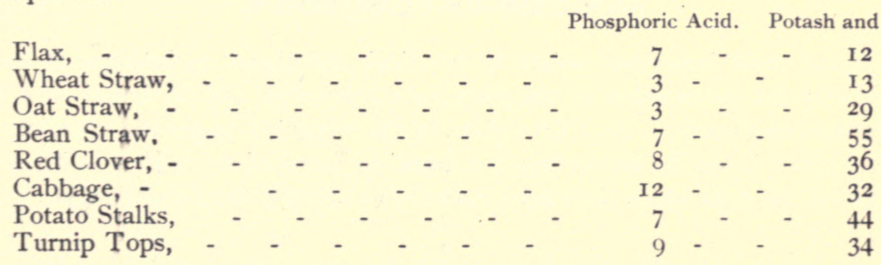

According to Dr. Lyon Playfair, a crop of wheat, at the rate of 25 bushels of grain and $3000 \mathrm{lbs}$. of straw, will take from the land $175 \mathrm{lbs}$. of inorganic matter ; beans, 23I lbs.; 
clover, 259 lbs.; turnips, $640 \mathrm{lbs}$,, - and according to Johnson, barley, $213 \mathrm{lbs}$., and oats, $326 \mathrm{lbs}$; ; all of which is considerably more than Flax appropriates.

All that the Flax crop takes from the land remains in the steep-water and in the chaff of the scutched Flax; and if, after suitable decomposition of the latter, all this was returned to the soil, its fertility would be restored, and thus, materials at present utterly neglected and even a mere incumbrance, might be converted into valuable manures, for as Prof. Liebig states, the seed and chaff of the Flax plant is rich in phosphates.

It must, however, be remarked here, that the immense quantity of weeds with which the western farmer allows his Flax field to be overgrown, are immeasurably more exhausting to the land than the crop grown on it, which, on account of its meagerness, both as regards seed and straw, has only a small part to play in the process of exhaustion.

Much other testimony from reliable and competent sources might be brought forward to prove that Flax has been traduced, and in no degree deserves the stigma that has been attached to it, as an exhaustive crop. It is well known that Egypt was the great Flaxgrowing land of antiquity ; but at the same time it was also the granary of the world! In Belgium, where the relative area under Flax is greater than in any other country, the fertility of the soil has been constantly improving for centuries. "The reason of this," says Robert Scott Burn, " is that Flax culture involves good husbandry," and " Flax cultivation "and bad cultivation are quite incompatible."

A Dorsetshire gentleman writes, (Bath Society papers, 1871 ): "One peculiar advantage "attending the cultivation of hemp and flax is that a crop of the former prepares the land " for the latter, and therefore a crop of hemp is clear gain to the farmer. That these " plants impoverish the soil is a mere vulgar notion devoid of all truth. The best historical "relations and the verbal accounts of honest ingenuous planters concur in declaring it to be " a vain prejudice unsupported by any authority ; and that these crops really ameliorate and " improve the soil."

It is a well-known and significant fact that the finest crops of wheat may be grown immediately after Flax in rotation. Thus, not only do scientific analyses, and the experiments and observations of eminent agricultural writers go to show that prejudice against Flax is to a great degree unfounded, but experience with Flax in the rotation of crops also proves that it is not a crop to be avoided for its alleged impoverishment of the soil.

Another objection that is sometimes made to Flax culture is that it "requires so much farm help." There is no doubt that Flax to be a successful crop, requires much more careful cultivation, weeding, etc., than most other products, but it may be remarked on the other hand, that if properly treated it will be much more remunerative than any other crop, and thus amply compensate the farmer for his extra trouble and outlay. Careful cultivation cannot be too emphatically insisted upon. The pains-taking culturist will obtain the maximum, and he that is careless and slovenly, the minimum result in Flax raising.

\section{ANALYSIS OF FLAX SOILS.}

One of the most important points in practical, intelligent agriculture, is to become acquainted with the composition of the plant to be cultivated, and to know what soils are best adapted to its growth. As I have given in the foregoing pages the chemical analysis of the Flax plant, it may be interesting and useful to many of my readers to know also the composition of the soils which have been found most suitable for its cultivation. 
Following is the result of analyses made by Sir Robert Kane, of four excellent Flax soils :-Nos. I, 2 and 3 being Irish, and No. 4, Belgian :

\begin{tabular}{|c|c|c|c|c|}
\hline & No. I. & No. 2. & No. 3 . & No. 4 . \\
\hline Silica and Siliceous Sand. & 73.72 & $69.4 \mathrm{I}$ & 64.93 & 92.78 \\
\hline Oxide of Iron..$\ldots \ldots \ldots \ldots \ldots$ & $5 \cdot 5 \mathrm{I}$ & 5.29 & 5.64 & 0.66 \\
\hline Alumina $\ldots \ldots \ldots \ldots \ldots \ldots \ldots \ldots \ldots$ & 6.65 & $5 \cdot 70$ & 8.97 & I. II \\
\hline Phosphate of Iron.................. & 0.06 & 0.25 & 0.31 & $0.2 I$ \\
\hline Carbonate of Lime $\ldots \ldots \ldots \ldots \ldots \ldots \ldots$ & 1.09 & 0.53 & I.67 & 0.35 \\
\hline $\begin{array}{l}\text { Magnesia and Alkalies, with traces of } \\
\text { Sulphuric and Muriatic Acids... }\end{array}$ & 0.32 & 0.25 & 0.45 & O.I 2 \\
\hline Organic matter..$\ldots \ldots \ldots \ldots \ldots \ldots \ldots \ldots$ & 4.86 & 6.67 & $9 \cdot 4 \mathrm{I}$ & 2.74 \\
\hline Water $\ldots \ldots \ldots \ldots \ldots \ldots \ldots \ldots \ldots \ldots \ldots \ldots \ldots$ & $7 \cdot 57$ & II. 48 & 8.73 & 2.03 \\
\hline Totals . & 99.78 & $99 \cdot 5^{8}$ & IOO. I I & 100.00 \\
\hline
\end{tabular}

It should be added that the organic matter, which ranged from 2.74 to $9.4 \mathrm{I}$ per cent, was rich in nitrogen, which fact, of course, had much to do with the fertility of the soils.

\section{IN CONCLUSION.}

This pamphlet being intended especially as a treatise on Flax growing, for the benefit of farmers interested in that industry, I do not enter into a discussion of the different methods of "retting," and preparing the fiber for market. As I have heretofore intimated, this cannot be undertaken by the farmer without adding greatly to his labors, which in many instances are already too onerous. The preparation of the fiber belongs to the province of the manufacturer, and requires, in addition to a thorough knowledge of the various processes, . the employment of expensive machinery. Therefore, in the development of this important industry in the United States, a practical recognition of its natural divisions cannot be ignored, as otherwise it can never attain the proportions commensurate with its value, and with the extraordinary facilities and resources here afforded.

To the public-spirited and patriotic who are interested in the progress of American Agriculture, a broad field is open for investigation and profitable enterprise.

It would appear to be necessary only to call attention to the important facts relating to Flax culture in this country, to create a vital and growing interest in the subject. We may hope that ere long the formation of a Society for the promotion of Flax culture in this country will be found desirable. Such an organization would have a powerful influence and grand opportunities. It might readily give such an impetus to a most important industry as to increase the wealth of the nation by many millions of dollars annually.

Then, instead of American Flax culture remaining a synonym for gross waste, in the destruction of vast quantities of valuable raw material, it would speedily become one of the most popular and profitable of our agricultural industries. 


\section{APPENDIX.}

The following diagrams show the areas devoted in 1880 to the cultivation of Flax in the principal Flax-producing countries of the world, with the approximate quantity of Flax fiber produced, in tons of $2240 \mathrm{lbs}$.

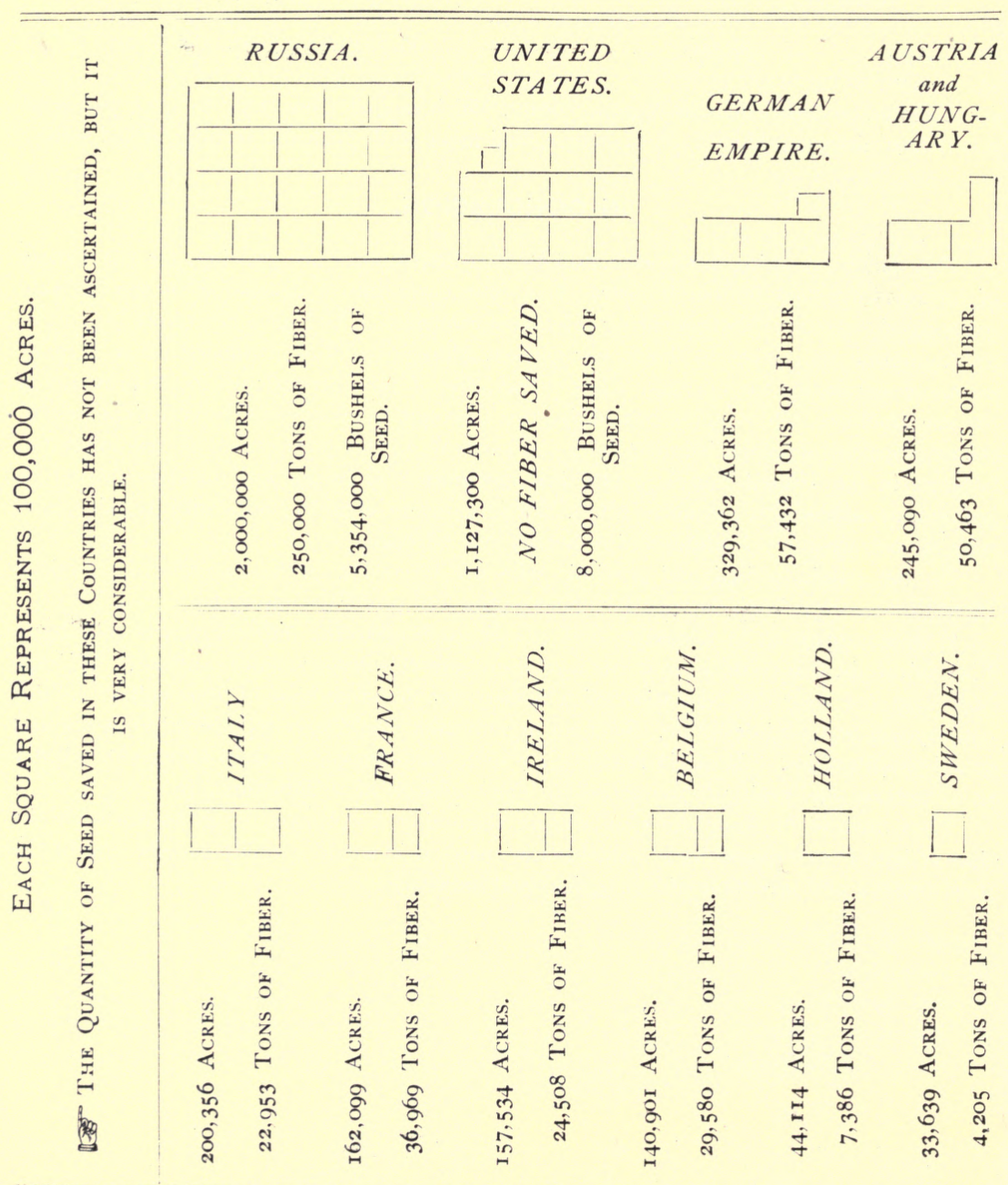


SUMMARY OF THE AREA DEVOTED IN I880 TO THE CULTIVATION OF Flax IN THE Fol lowing Countries, with the Quantity of Flax Fiber produced in Each Country, The approximate Total VAlue of SAME, AND THE APProximate YIELD PER ACRE, VIZ:

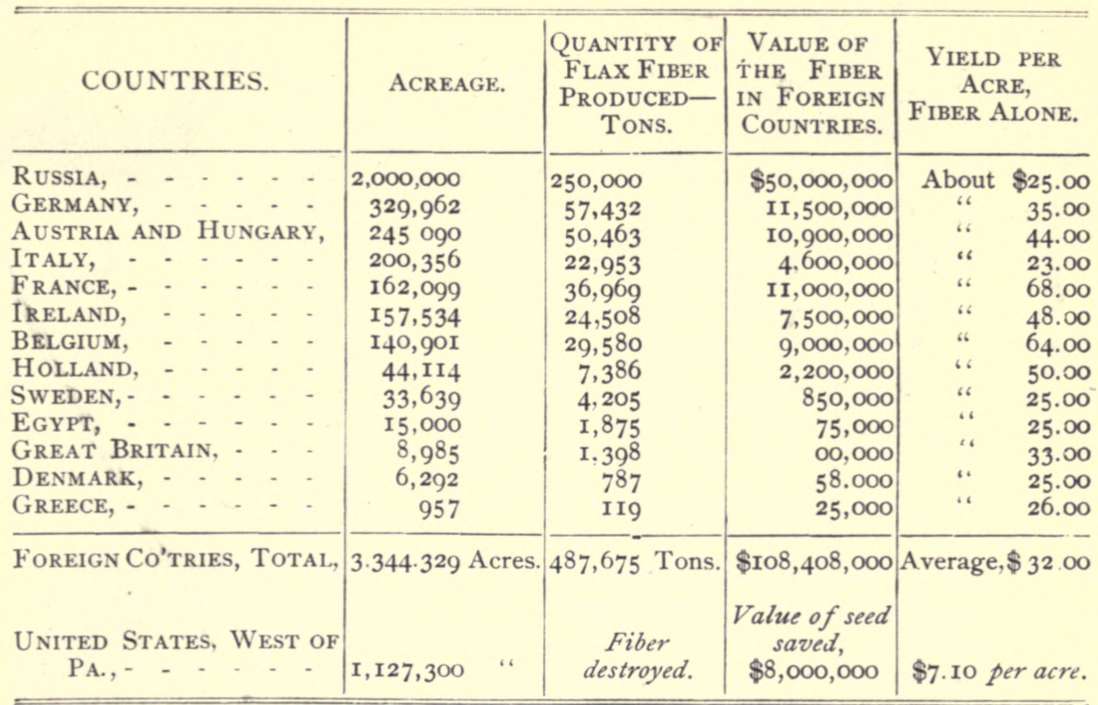

AREA UNDER FLAX IN I88I IN THE FOLLOWING StATES, VIZ :

IowA, - 287,400 Acres.

INDIANA, - I93,400

KANSAS, - I60,900

ILLINOIS, - 160,300

Minnesota, 92,200

OHIO, - - 80,600

Missouri, - 55,000

NEBRASKA, - 50,000

WISCONSIN, 44,500

Total, - I, I27,300 Acres.

No merchantable Flax Fiber produced.

Total Quantity of Flax SEED SAVED ON THIS AREA ABOUT (bushels) 8,000,000

VALUED AT - $\$ 8,000,000$

The average yield in Europe The average yield in Europe FLAX MANUFACTURES, - - - - - - - I98, 768,942 In the Western States the seed yields only \$7.10 peracre.

\section{IMPORTS INTO THE UNITEDSTATES.}

\author{
RAW FLAX.
}

From I 87 I to I880, 39,480 Tons-Valued at $\$ 10,986,469$

In I88I, - - $-5,446$ " 2 i, 462,286

Total, 44,962 Tons-Valued at \$12,448, 745

FLAX MANUFACTURES.

From I87I to I880, - . . . - $\$ 177,748,317$

In I88I, - . - . - . . - . - 2I,020,57I

Total, - - - $\$ 198,768,942$

HEMP, JUTE AND OTHER Fibers AND Products THEREOF.

From I87I to I880, - . - . - - $\$ 80,6$ II, 758

In I88I, - . . - . - . - . I9,558,126

TOTAL, _ - - - \$9I, I69,884

TOTAL VALUE OF OUR IMPORTS FROM I87I TO I88I. RAW FlAX, - - - - - - - - - \$I2,448,745 HEMP, JUTE, ETC., and manufactures thereof, 9I, I69,884 Total, - . - $\$ \overline{\$ 302,387,571}$ 
RECEIPTS AT ST. LOUIS OF HEMP, FLAX AND JUTE.

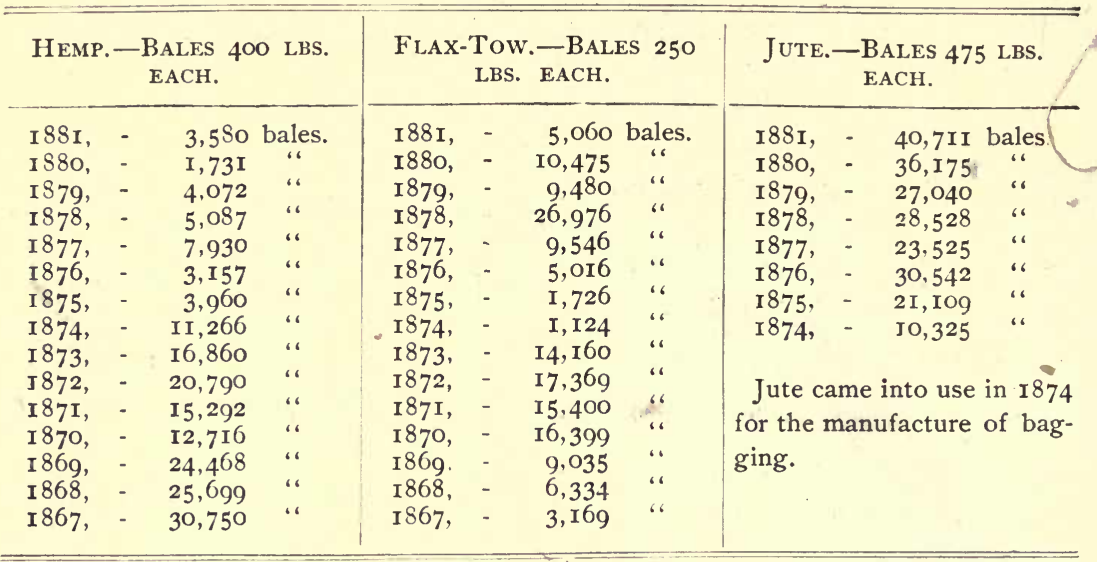

IMPORTS OF FOREIGN DRY GOODS at the Port of New York, and Value of Flax Pronucts included therein, SHOWING THE PROPORTION OF THE LATTER in OUR ANNUAl Imports, VIz.:

Total Value of Dry Value of Flax GoOdS IMPORTED. Products.

\begin{tabular}{|c|c|c|}
\hline ISSI, & - $\quad \$ 124,522,695$ & $\$ 2 \mathrm{I}, 020,57 \mathrm{I}$ \\
\hline I 8So, & I08,910 993 & $23,730,326$ \\
\hline I 879 & II $3,337,007$ & $15.663,288$ \\
\hline I 878 & $79,606,048$ & I $5,590,829$ \\
\hline I877, & $74,7 \mathrm{I} 7,03 \mathrm{I}$ & $17,075,217$ \\
\hline I 876 & $88,058,966$ & I $9,365,979$ \\
\hline I 875, & $106,501,249$ & $23,942,659$ \\
\hline I 874 & I06, 706,644 & $22,7 \mathrm{I} 6,483$ \\
\hline I873, & I25,086,09I & $25,420,589$ \\
\hline I 872 & I $39,903,902$ & $26,938,273$ \\
\hline I 87I, & I26, I 23, 2 IO & $23,916,474$ \\
\hline I 870, & $96,414,276$ & $2 \mathrm{I}$, OII, $7 \mathrm{I} 8$ \\
\hline I 869, & $92,499,846$ & I $8,765,74 \mathrm{I}$ \\
\hline I 868, & $77,254,192$ & I7,94I,094 \\
\hline I 867, & $103,407,278$ & $25,795,410$ \\
\hline I 866, & $137,056,834$ & $27,227,039$ \\
\hline I 865 & $49,853,939$ & II $, 945,585$ \\
\hline
\end{tabular}

RES U MÉ.

On the immense area of $1,127,300$ acres, second only to Russia, we annually raise Flax seed to the value of $\$ 8,000,000$, (about \$7.ro per acre), while four-fifths of the Flax straw produced being through careless and improper cultivation of too inferior a quality, is wasted, and a very small quantity is turned into coarse tow for upholsterers, or used for cotton bayging or twine, or given as feed to cattle.

The value of the product of Flax fiber and seed in Russia, on an area of 2,000,000 acres, is above $\$ 60,000,000$, or more than $\$ 30$ per acre. Belgium, on an area of I40,90I acres, or one-eighth of the area under Flax in the Western States, annually produces $\$ 1,000,000$ more than we. France, on an area of 162,099 acres, or exactly one-seventh of the area under Flax in the United States, produces $\$ 3,000,000$ more than we. Sweden, on an area of 33,639 acres, or one thirty-

fourth of our Flax area, would nearly cover the present demand of our home industry. Our imports of Raw Flax, Linen manufactures, Hemp, Fute, and other fibers and manufactures thereof, during a period of eleven years, from $187 \mathrm{I}$ to $I 88 \mathrm{I}$ inclusive, have drained the land of the enormous sum of $\$ 302,387,57$ I. 


\section{SIBLEY'S PUBLICATIONS.}

Flax Culture for Seed and Fiber. Price, io cents.

Grain and Farm Sfepd Manual, containing the oniy correct history of Indian Corn ever written, histories of Wheat and other cereals, and Potatoes, by Dr. E. L. Sturtevant, Director of the N. Y. Agricultural Experiment Station; valuable, practical articles on Grasses and on Wheat and Corn cultivation, by Prof. W. J. Beal, of Michigan Agricultural College, and B. F. Johnson, of Illinois; methods of culture and descriptions of all the valuable new and standard varieties of plants used in field culture. Price, Io cents.

Sibley's Farmers' Almanac-Northern edition; containing valuable articles on the culture of special crops, by the best American writers; calendars of farm work, and descriptions of varieties of farm and garden plants. Price, ro cents.

Sibley's Farmers' Almanac-Southern edition; contains practical essays on southern gardening and farm practice, by successful southern planters and gardeners ; calendars, and descriptions of varieties, etc. Price, Io cents.

Annual Descriptive Catalogue and Price List of Flower, Garden, Field and Tree Seeds and Plants of all the valuable, new, and standard varifties; fully illustrated, and with condensed essays on the culture of each class of plants, by experienced culturists. Free.

Fall Catalogue of Flowering Bulbs and Plants for the house, conservatory and gazden; fully illustrated; written by an experienced horticulturist. Free.

Implement Catalogue, containing full descriptions of a large variety of the best farm and garden implements; handsomely illustraterl. Free.

BOok CATALOGUE of all the best books for the farm and garden. Free.

Viarket Gardeners' Catalogue, descriptive Price List of new and standard varieties for market garden culture. Free.

Sprixg Plant List of Cabbage, Cauliflower, Tomato, Sweet Potato, Celery, and other plants for market and family gardens. Free. 
UNIVERSITY OF CALIFORNIA LIBRARY, BERKELEY

THIS BOOK IS DUE ON THE IAST DATE STAMPED BELOW

Books not returned on time are subject to a fine of $50 \mathrm{c}$ per volume after the third day overdue, increasing to $\$ 1.00$ per volume after the sixth day. Books not in demand may be renewed if application is made before expiration of loan period.

10

40V 811927

NOV

91925

$120 e^{150} \mathrm{BL}$

$50 m-8,26$

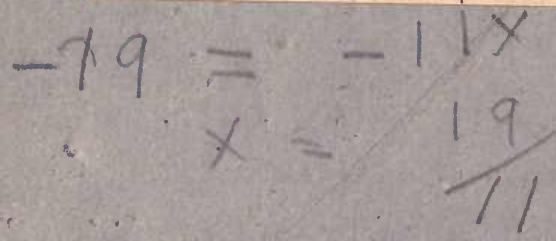




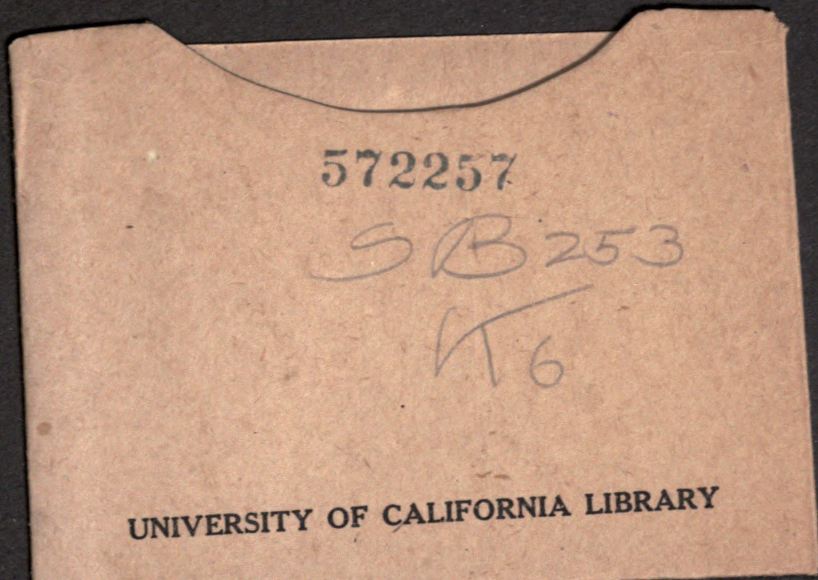




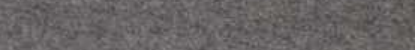

